\title{
EXPERIMENTAL STUDY OF POST INSTALLED REBAR ANCHOR SYSTEMS FOR CONCRETE STRUCTURE
}

\author{
Haidar H. HAIDAR ${ }^{1}$, Faten I. MUSSA ${ }^{1}$, Abbas O. DAWOOD ${ }^{1,{ }^{*},}$ Ahmed A. GHAZI ${ }^{1}$, \\ Rassel A. GABBAR ${ }^{1}$ \\ ${ }^{1}$ Department of Civil Engineering, University of Misan, Iraq. \\ corresponding author: abbasoda03@uomisan.edu.iq.
}

\section{Abstract}

This study investigated the effectiveness of several types of adhesives used in post-installed rebar connections as a bonding agent between steel reinforcement bars and old concrete under pull out test. The experimental samples were; cylindrical samples of (150 $\mathrm{mm}$ dia. $\times 300 \mathrm{~mm}$ high) with anchors rebar of varying diameter (12 and $16 \mathrm{~mm}$ ), different embedded length $(100$ and 150) $\mathrm{mm}$ with different holes' diameters. The strategy of control were cast-in-place rebar concrete specimens while other samples are post-installed rebar concrete specimens of varied chemical adhesives as bonding agents, namely KUT EPOXY ANCHOR 'NS' and SIKAFLOOR169. The output showed that the different adhesives yielded closed pull-out load values. It is found that the pull-out capacity (bond strength) is increased by increasing the embedded length, the diameter of the rebar and slightly with the diameter of the hole. In addition, the failure mode of post-installed rebar concrete was governed by the embedded length and the area of contact with the adhesives. On the other hand, the larger diameter of rebar favors splitting or failure of concrete due to higher strength in binder-rebar interface compare to the binderconcrete interface. The results showed that the pull-out load was increased by $(26 \%$ and $32 \%)$ as the rebar diameter increased from $12 \mathrm{~mm}$ to $16 \mathrm{~mm}$ for KUT "NS" and SIKAFLOOR respectively. The hole diameter had slightly effect of the pull out load where the average of increment was only $6 \%$. Finally, the bonding strength is considerably depended on the embedded length and less affected by the type of epoxy.
\end{abstract}

\section{Keywords:}

Kut epoxy anchor;

Failure mode;

Adhesive bonded anchor;

Pull-out test;

SIKAFLOOR.

\section{Introduction}

Anchors in reinforced concrete structures are often used either in the rehabilitation of existing structures or attaching equipment to the base material. Anchors to concrete can divide into two general categories as cast-in-place anchors and post-installed anchors [1]. Cast-in- place anchors embedded in the concrete before it hardens. Advantages of the cast in place anchors are their predictable and more reliable behavior and failure modes [1], but require a high level of accuracy in their placement to ensure proper alignment as they cannot be moved after the concrete hardens so cast-in-place anchors provide less flexibility to the designer than post-installed anchors [1]. Post installed anchor installed into a hardened concrete member by drilling holes and inserting the bar with binders or adhesives. This method used for different purposes such as binding new concrete to the old or pre-existing one; this enables continuity, strengthening, or homogenous stress transfer in the structures using additional reinforcing or transference bars. It is known that the transfer of load or stress in reinforced concrete is based on the bond between the reinforcing steel and the surrounding concrete or binders. This transfer is provided by the resistance to relative motion or slippage between the concrete and the rib faces of the embedded steel bar. The resistance to slippage alternatively known as the bond strength that depends on three actions: chemical adhesion, friction, and mechanical interaction between the ribs of the bar and the surrounding concrete [2]. The variables 
considered for each concrete block were the type of drilling machine used for drilling the hole, type of filling material, moisture conditions of the hole during installation, cleanliness of the hole, and installation direction [3]. There are five main failure modes of post-installed anchors in concrete, as shown in Fig. 1 steel failure (shear), pull-out failure, concrete cone failure, concrete splitting failure and space, edge cone failure [3]. There are several studies available in literature related to the behavior of the rebar anchor system. The experimental investigation of the behavior of the anchorage system and the effectiveness of chemical adhesive used in post-installed rebar connections accomplished in several studies. The connection behavior was studied in term of pull out test and bonding strength via different parameters included, the effect of thickness of adhesive, bar diameter, embedment length, steel strength, concrete strength, aggregate compositions, and the layout of an anchorage system, single and group anchors tests programs on connection behavior was presented [2 - 17].

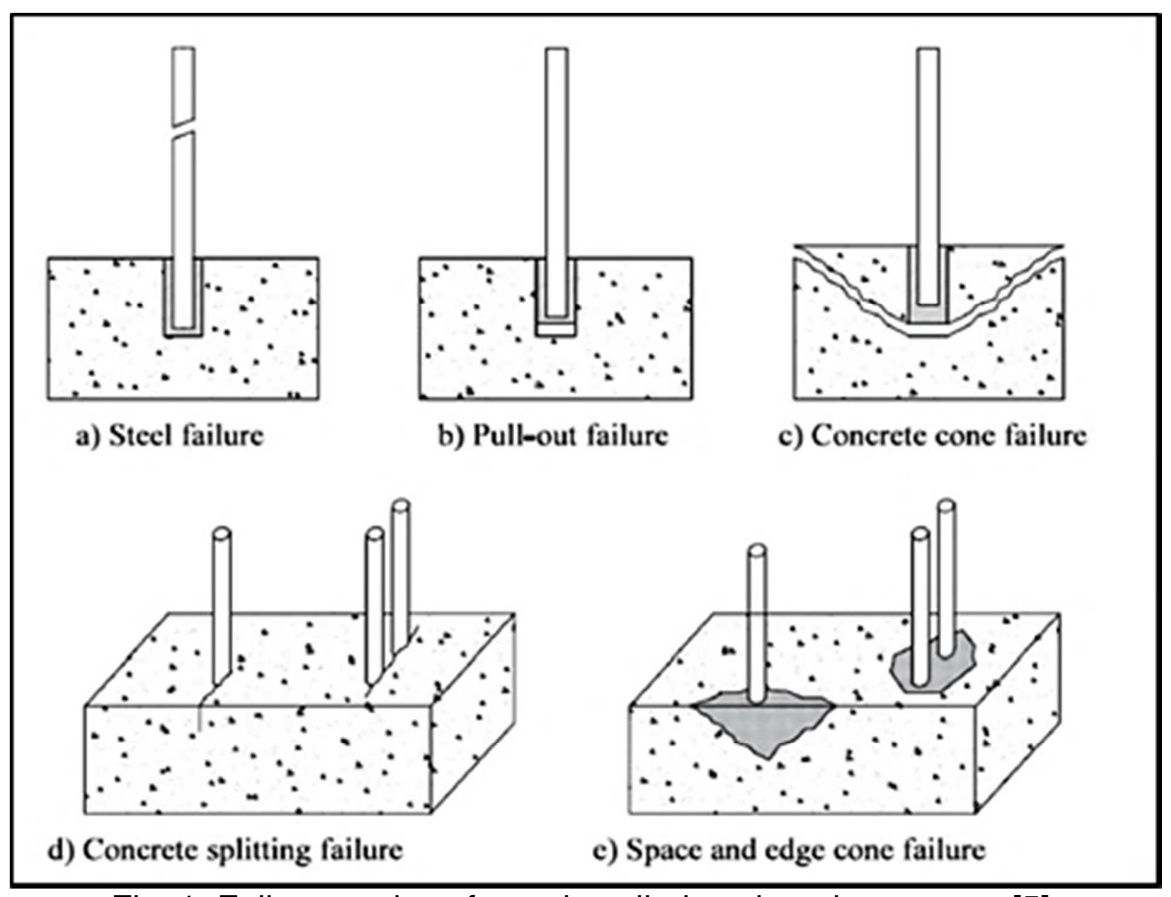

Fig. 1: Failure modes of post-installed anchors in concrete [5].

\section{Experimental works}

\subsection{General description of test specimens}

The main purpose of the test program is to study the behavior of the rebar anchor system that was inserting in unreinforced concrete cylinders and to be failed in the pull-out test. The average cylindrical concrete compressive strength of 28 days' age was $25 \mathrm{MPa}$. Within the scope of the study, the anchor's (steel bars) diameter was 12 and $16 \mathrm{~mm}$, the embedment length $\left(L_{D}\right)$ were 100 and 150 $\mathrm{mm}$, and the diameter of hole $\left(d_{h}\right)$ in post-installed anchor system was; diameter of the bar $\left(d_{b}\right)$ addition $2 \mathrm{~mm}$, diameter of the bar $\left(d_{b}\right)$ addition $4 \mathrm{~mm}$. The dimensions of concrete cylinders manufactured for test specimens were $150 \mathrm{~mm}$ diameter $\times 300 \mathrm{~mm}$ height. The experimental program includes the preparation and testing of sixteen specimens. The specimens divided into two groups according to the type of the anchor system: cast-in-place and post-installed. Four specimens for castin-place as control, and twelve specimens for post-installed. In the post-installation system, it was used two types of epoxy adhesives, i.e., KUT "NS" and SIKAFLOOR. Table1 provides the information about groups of specimens. 
Table 1: Test specimen configurations.

\begin{tabular}{|c|c|c|c|c|c|}
\hline Group & $\begin{array}{l}\text { Anchor } \\
\text { system }\end{array}$ & $\begin{array}{c}\text { Diameter of bars } \\
\left(d_{b}\right) \mathrm{mm}\end{array}$ & $\begin{array}{c}\text { Diameter of holes } \\
\left(d_{h}\right) \mathrm{mm}\end{array}$ & $\begin{array}{l}\text { Embedment length } \\
\left(L_{D}\right) \mathrm{mm}\end{array}$ & Type of epoxy \\
\hline \multirow{4}{*}{$\begin{array}{l}\text { Group } \\
\text { one }\end{array}$} & \multirow{4}{*}{ Cast-in place } & \multirow{2}{*}{12} & --- & 100 & --- \\
\hline & & & --- & 150 & --- \\
\hline & & \multirow[t]{2}{*}{16} & --- & 100 & --- \\
\hline & & & --- & 150 & --- \\
\hline \multirow{12}{*}{$\begin{array}{l}\text { Group } \\
\text { two }\end{array}$} & \multirow{12}{*}{ Post-installed } & \multirow{8}{*}{12} & 14 & 100 & KUT "NS" \\
\hline & & & 16 & 100 & KUT "NS" \\
\hline & & & 14 & 150 & KUT "NS" \\
\hline & & & 16 & 150 & KUT "NS" \\
\hline & & & 14 & 100 & SIKAFLOOR \\
\hline & & & 16 & 100 & SIKAFLOOR \\
\hline & & & 14 & 150 & SIKAFLOOR \\
\hline & & & 16 & 150 & SIKAFLOOR \\
\hline & & \multirow{4}{*}{16} & 18 & 150 & KUT "NS" \\
\hline & & & 20 & 150 & KUT "NS" \\
\hline & & & 18 & 100 & SIKAFLOOR \\
\hline & & & 20 & 100 & SIKAFLOOR \\
\hline
\end{tabular}

\subsection{Materials}

The materials used in this study are commercially available, included concrete, steel reinforcement, and epoxy.

\subsubsection{Cement}

The commercially ordinary Portland cement used in this study Type I. The physical properties of the cement tested according to Iraqi Standard No. 5/1984 [18] were presented in Table 2.

Table 2: Physical properties of ordinary Portland cement.

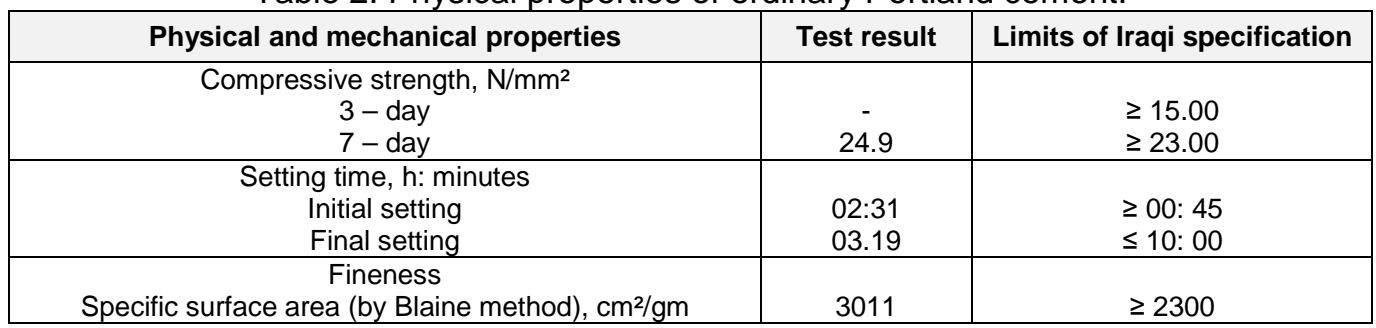

\subsubsection{Aggregate}

Natural sand brought from Al-Zubair in the south of the Iraq area used as a fine aggregate in this work. The grading test of the fine aggregate is shown in Table 3. The obtained results indicated that the fine aggregate grading and the sulfate content are within the limits of the Iraqi specification number (45/1984) for zone No.1 [18]. Sulfate content, specific gravity, moisture content, and absorption of the fine aggregate shown in Table 4.

Table 3: Grading of fine aggregate.

\begin{tabular}{|c|c|c|c|}
\hline No & Sieve size $(\mathbf{m m})$ & \% of passing fine aggregate & Specification \\
\hline 1 & 4.75 & 97.76 & $90-100$ \\
\hline 2 & 2.36 & 81.41 & $60-95$ \\
\hline 3 & 1.18 & 63.9 & $30-70$ \\
\hline 4 & 0.6 & 32.43 & $15-34$ \\
\hline 5 & 0.3 & 9.73 & $5-20$ \\
\hline 6 & 0.15 & 0.45 & $0-10$ \\
\hline
\end{tabular}


Table 4: Properties of fine aggregate.

\begin{tabular}{|c|c|c|}
\hline Physical properties & Test results & Iraqi specification \\
\hline Specific gravity & 2.65 & - \\
\hline Sulfate content & $0.3 \%$ & Not more than $0.5 \%$ \\
\hline Absorption & $1 \%$ & - \\
\hline
\end{tabular}

Crushed gravel from the Chlat area in Misan south of Iraq with a maximum size of $20 \mathrm{~mm}$ used. The grading of the coarse aggregate is shown in Table 5. Results show that the grading is within the requirements of Iraqi Specification No. 45/1984 [18]. Table 6 shows the specific gravity, sulfate content and absorption of the used course aggregate.

Table 5: Grading of coarse aggregate.

\begin{tabular}{|c|c|c|c|}
\hline No. & Sieve size $(\mathbf{m m})$ & (\%) of passing coarse aggregate & Specification \\
\hline 1 & 19 & 97 & $100-95$ \\
\hline 2 & 10 & 36 & $30-60$ \\
\hline 3 & 4.75 & 2 & $0-10$ \\
\hline
\end{tabular}

Table 6: Properties of coarse aggregate

\begin{tabular}{|c|c|c|}
\hline Physical properties & Test results & Specification \\
\hline Specific gravity & 2.67 & - \\
\hline Sulfate content & $0.07 \%$ & Not more than $0.1 \%$ \\
\hline Absorption & $0.6 \%$ & - \\
\hline
\end{tabular}

\subsubsection{Superplasticizer}

The superplasticizer used was a type (Sika Viscocrete 5930L). Which was highly effective in the production of free-flowing concrete. In addition, it enhances the early and ultimate strength of concrete by reducing substantial water.

\subsubsection{Concrete}

A normal concrete used for all the test specimens. The concrete constituent materials proportioned and weighed then mixed in a rotary mixer. The average compressive strength of concrete obtained by using a cylinder molding $(150 \times 300) \mathrm{mm}$. The value was $25 \mathrm{MPa}$ at 28 days with (slump test $=100 \mathrm{~mm}$ ). The curing process done according to ASTM C192.The properties of the mix used as shown in Table 7.

Table 7: Properties of the mix used.

\begin{tabular}{|c|c|c|c|c|c|c|}
\hline $\begin{array}{c}\text { Type of } \\
\text { concrete }\end{array}$ & $\begin{array}{c}\text { Cement content } \\
\mathbf{~ k g} / \mathbf{m}^{\mathbf{3}}\end{array}$ & $\begin{array}{c}\text { Sand } \\
\mathbf{k g} / \mathbf{m}^{3}\end{array}$ & $\begin{array}{c}\text { Gravel } \\
\mathbf{~} \mathbf{g} / \mathbf{m}^{3}\end{array}$ & $\begin{array}{c}\text { Water } \\
\mathbf{k g} / \mathbf{m}^{3}\end{array}$ & $\begin{array}{c}\text { W/C } \\
\text { ratio }\end{array}$ & $\begin{array}{c}\text { Sp.\% by weight of } \\
\text { cement }\end{array}$ \\
\hline Normal concrete & 300 & 450 & 900 & 135 & 0.45 & $0.2 \%$ \\
\hline
\end{tabular}

\subsubsection{Steel reinforcement}

Two grades of reinforcement bars used in this research are 12 and $16 \mathrm{~mm}$ diameter. The properties of these bars are shown in Table 8.

Table 8: Properties of steel bars.

\begin{tabular}{|c|c|c|c|}
\hline $\begin{array}{c}\text { Dim. } \\
(\mathbf{m m})\end{array}$ & $\begin{array}{c}\text { Area } \\
(\mathbf{m m})\end{array}$ & $\begin{array}{c}\text { Yield strength } \\
(\mathbf{M P a})\end{array}$ & $\begin{array}{c}\text { Ultimate strength } \\
\text { (MPa) }\end{array}$ \\
\hline 12 & 113.14 & 517.83 & 689.2 \\
\hline 16 & 201.14 & 569.94 & 704.8 \\
\hline
\end{tabular}

\subsubsection{Application of epoxy based adhesives}

Two types of adhesives used for post-installed reinforcement. The first one was KUT EPOXY ANCHOR 'NS', which is a three-component product consisting of a base, hardener, and filler supplied 
in pre-measured quantities ready for mixing and using. Its special epoxy can be used for anchoring of bolts and bars from 12 to $51 \mathrm{~mm}$ diameter into concrete, rock, masonry or brickwork. This type of epoxy has a compressive strength of about $75 \mathrm{MPa}$ after 24 hours and the shear strength greater than $35 \mathrm{MPa}$ [19]. The second type was SIKAFLOOR169, which is a two-part epoxy binder for mortars, screeds, and seal coats. This type has good mechanical and abrasion resistance, produced with a minimum compressive strength about $25 \mathrm{MPa}$ and a minimum pull-off strength of $1.5 \mathrm{MPa}$. For anchoring applications, the epoxy mortar produced by SIKAFLOOR169 should mixed with SIKA DUR 504 that was quartz sand (filler) with size 0.1 to $0.3 \mathrm{~mm}$ by the ratio (1 part of epoxy to 1 part of quartz sand) by weight.

For the post-installed anchor system, the cylindrical boreholes with a depth of (100 and 150 $\mathrm{mm}$ ) drilled using an electric rotary hammer drill with a 14, 16, 18, and $20 \mathrm{~mm}$ diameter drill bit. The boreholes cleaned using compressed air to remove all the loose concrete particles as shown in Fig. 2. Then the epoxy adhesives mixed individually (KUT epoxy anchor" NS" and SIKAFLOOR169) according to the manufacturer's guides. The next step poured in the holes as shown in Fig. 3. The anchor rod inserted manually with rotation as shown in Fig. 4. After a one-hour gel period, the excessive adhesive that poured out of the holes removed from the concrete surface.

For cast-in-place anchor system, the process included, select the length of embedment for anchor bars, center and insert the anchor bar in fresh concrete within the mold in which a cross shape steel frame used to avoid the moving of bars during concrete pouring in molds as shown in Fig. 5.

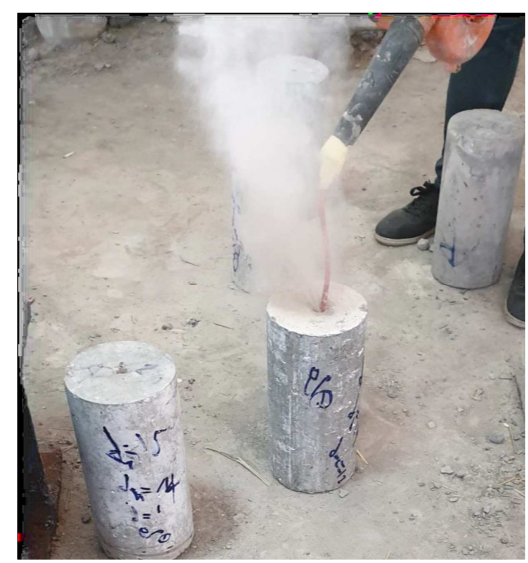

Fig. 2: Cleaning the boreholes.

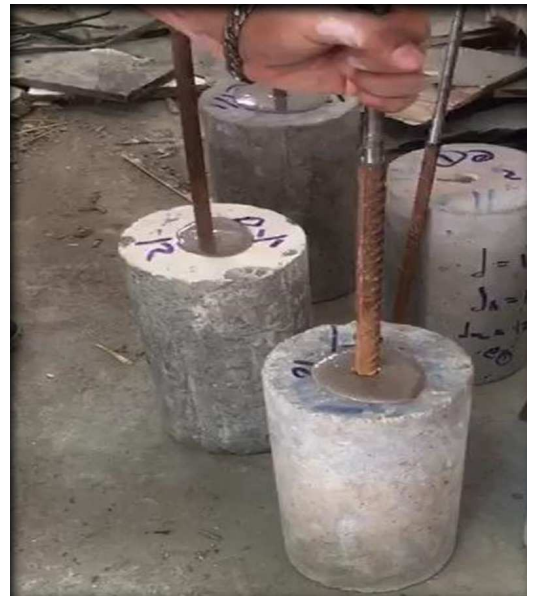

Fig. 4: The anchor rod inserted manually.

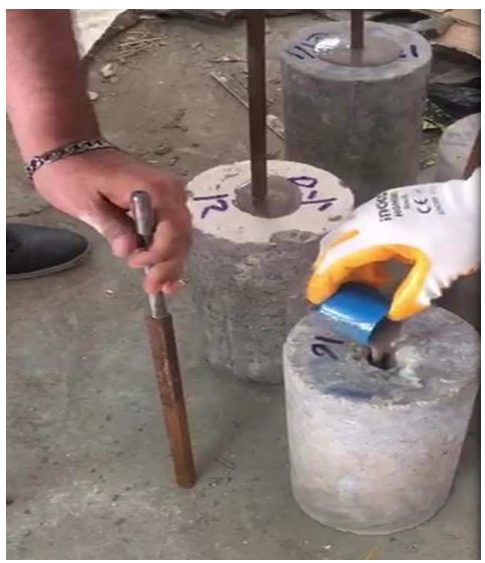

Fig. 3: The epoxy poured in the holes after mixed.

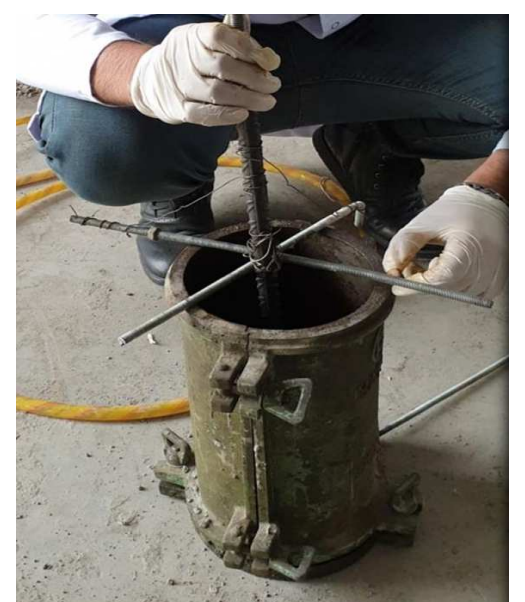

Fig. 5: The steel frame as a cross shape.

\subsection{Pull-out test}

The pull-out test carried out after 14 days of installation of the anchors. Fig. 6 shows the load applied to the anchors at the loading rate of $20 \mathrm{kN} / \mathrm{min}$. This test applied until reaching the failure load as shown in Fig. 7. A load cell attached to the system to record the failure loads for each case, where 
the information of the embedded lengths, the diameter of the bar, the diameter of the hole, and the type of epoxy adhesive recorded on the concrete samples.

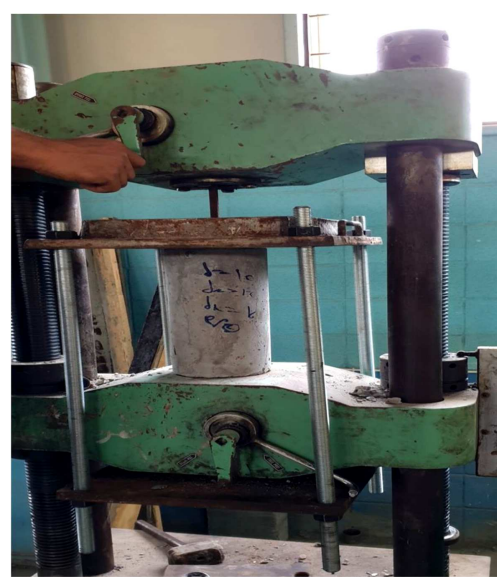

Fig. 6: Pull-out test device.
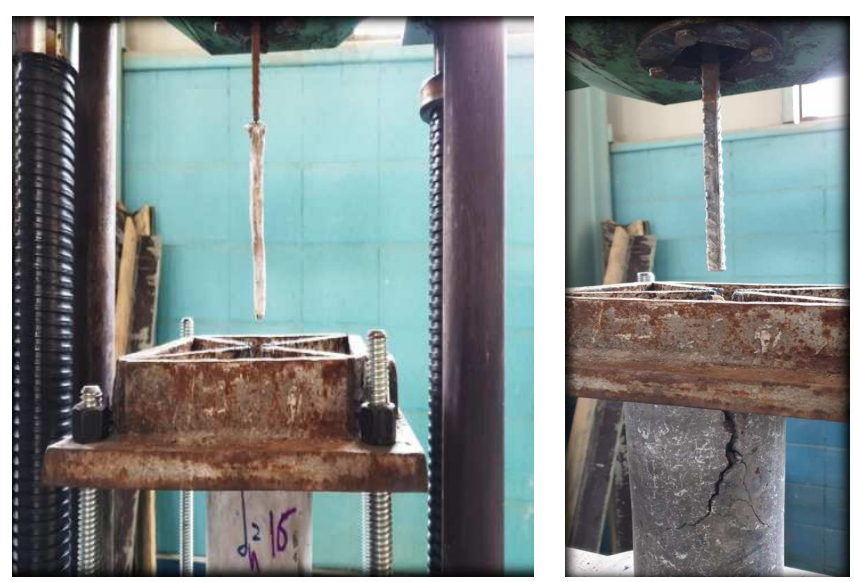

Fig. 7: Pull-out failure.

\section{Test results and discussion}

\subsection{Rebar diameter $\left(d_{b}\right)$ effect on pull-out capacity}

The effect of increasing the steel reinforcing bar diameter $d_{b}$ on bonding strength was examined by the pull-out test by using both types of epoxy adhesives Kut "NS" and SIKA FLOOR. Two diameters of steel bars $d_{b}$ considered for this comparison, namely 12 and $16 \mathrm{~mm}$. In general, the results recorded that the pull-out load directly increased as the diameter of the bar increased with the same embedment length as shown in Tables 9 and 10.

\subsubsection{Using KUT "NS"}

The effects of increases in the diameter of the bar $d_{b}$ examined by the pull-out test with using Kut "NS" for two rebar diameters, $d_{b}(12$ and $16 \mathrm{~mm})$. In general, the results recorded that an increase in pull-out load directly with the increase of the diameter of the bar as shown in Table 9 and Fig. 8. Where the maximum value of the pull-out test recorded was $48.51 \mathrm{kN}$ when $d_{b}=12 \mathrm{~mm}$ and $61.14 \mathrm{kN}$ when $d_{b}=16 \mathrm{~mm}$ with the same embedment length $L_{D}$ parameter, namely the pull-out load was increased by $26 \%$ as the rebar diameter increased from 12 to $16 \mathrm{~mm}$.

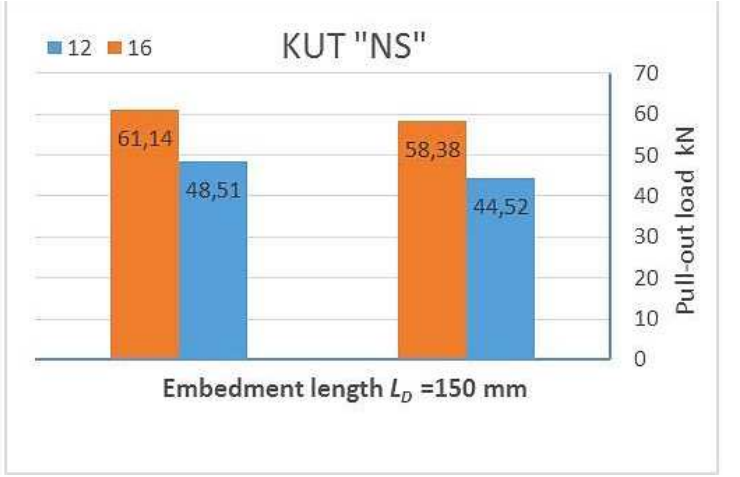

Fig. 8: The relation of pull-out load with the diameter of the bar for KUT "NS".

\subsubsection{Using SIKA FLOOR}

For SIKA FLOOR adhesive, Table 10 and Fig. 9 yielded that the maximum value of the pull-out load was $42.50 \mathrm{kN}$ and $56.28 \mathrm{kN}$ for rebar diameters of $d_{b}=12 \mathrm{~mm}$ and $d_{b}=16 \mathrm{~mm}$, respectively with the same embedment length $L_{D}$ parameter. This gives an increment in pull out load of $32 \%$ when the rebar diameter is increasing by $4 \mathrm{~mm}$. Hence, the surface area of anchor inside concrete increased as the rebar diameter increased. Thus it is clear that the increase of the pull-out load when bar diameter 
increased from 12 to $16 \mathrm{~mm}$ was proportional to the increasing in surface area of anchor system which leads to increasing the cohesion between an anchor and surrounding concrete.

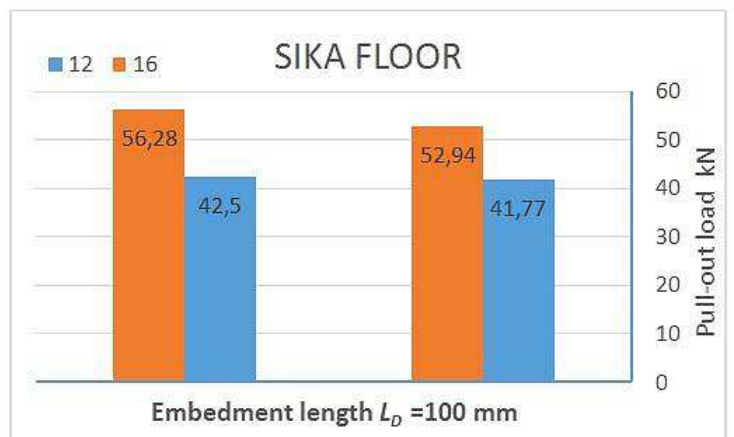

Fig. 9: The relation of pull-out load with the diameter of the bar for SIKAFLOOR.

Table 9: The results of pull-out loads for the two types of anchor system and KUT "NS".

\begin{tabular}{|c|c|c|c|c|c|c|c|}
\hline Groups & $\begin{array}{l}\text { Type of } \\
\text { anchor } \\
\text { system }\end{array}$ & $\begin{array}{l}\text { Epoxy } \\
\text { type }\end{array}$ & $\begin{array}{l}\text { Diameter of } \\
\text { bar }\left(d_{b}\right) \mathrm{mm}\end{array}$ & $\begin{array}{l}\text { Embedment } \\
\text { length }\left(L_{D}\right) \mathrm{mm}\end{array}$ & $\begin{array}{l}\text { Diameter of } \\
\text { hole }\left(d_{h}\right) \mathrm{mm}\end{array}$ & $\begin{array}{l}\text { Pull-out } \\
\text { load }(k N)\end{array}$ & Failure mode \\
\hline \multirow{4}{*}{$\begin{array}{l}\text { Group } \\
\text { one }\end{array}$} & \multirow{4}{*}{$\begin{array}{l}\text { Cast in } \\
\text { place } \\
\text { (control) }\end{array}$} & --- & \multirow{2}{*}{12} & 150 & --- & 76.59 & Concrete splitting failure \\
\hline & & --- & & 100 & --- & 68.74 & Concrete splitting failure \\
\hline & & --- & \multirow{2}{*}{16} & 150 & --- & 87.86 & Concrete splitting failure \\
\hline & & --- & & 100 & --- & 79.83 & Concrete splitting failure \\
\hline \multirow{6}{*}{$\begin{array}{l}\text { Group } \\
\text { two }\end{array}$} & \multirow{6}{*}{$\begin{array}{l}\text { post- } \\
\text { installed }\end{array}$} & \multirow{6}{*}{ KUT "NS" } & \multirow{4}{*}{12} & 150 & 14 & 44.52 & Concrete splitting failure \\
\hline & & & & 150 & 16 & 48.51 & $\begin{array}{l}\text { Concrete combined of splitting } \\
\text { and cone failure }\end{array}$ \\
\hline & & & & 100 & 14 & 43.56 & $\begin{array}{l}\text { Concrete combined of splitting } \\
\text { and cone failure }\end{array}$ \\
\hline & & & & 100 & 16 & 44.08 & $\begin{array}{l}\text { Concrete combined of splitting } \\
\text { and cone failure }\end{array}$ \\
\hline & & & \multirow{2}{*}{16} & 150 & 18 & 58.38 & $\begin{array}{l}\text { Concrete combined of splitting } \\
\text { and cone failure }\end{array}$ \\
\hline & & & & 150 & 20 & 61.14 & $\begin{array}{l}\text { Concrete combined of splitting } \\
\text { and cone failure }\end{array}$ \\
\hline
\end{tabular}

Table 10: The results of pull-out loads for the two types of anchor system and SIKAFLOOR.

\begin{tabular}{|c|c|c|c|c|c|c|c|}
\hline Groups & $\begin{array}{l}\text { Type of } \\
\text { anchor } \\
\text { system }\end{array}$ & $\begin{array}{l}\text { Epoxy } \\
\text { type }\end{array}$ & $\begin{array}{l}\text { Diameter of } \\
\text { bar }\left(d_{b}\right) \mathrm{mm}\end{array}$ & $\begin{array}{l}\text { Embedment } \\
\text { length }\left(L_{D}\right) \mathrm{mm}\end{array}$ & $\begin{array}{l}\text { Diameter of } \\
\text { hole }\left(d_{h}\right) \mathrm{mm}\end{array}$ & $\begin{array}{l}\text { Pole-out } \\
\text { load (kN) }\end{array}$ & Failure mode \\
\hline \multirow{4}{*}{$\begin{array}{l}\text { Group } \\
\text { one }\end{array}$} & \multirow{4}{*}{$\begin{array}{l}\text { Cast in } \\
\text { place } \\
\text { (control) }\end{array}$} & --- & \multirow{2}{*}{12} & 150 & --- & 76.59 & Concrete splitting failure \\
\hline & & --- & & 100 & --- & 68.74 & Concrete splitting failure \\
\hline & & --- & \multirow{2}{*}{16} & 150 & --- & 87.86 & Concrete splitting failure \\
\hline & & --- & & 100 & --- & 79.83 & Concrete splitting failure \\
\hline \multirow{7}{*}{$\begin{array}{l}\text { Group } \\
\text { two }\end{array}$} & \multirow{7}{*}{$\begin{array}{c}\text { post- } \\
\text { installed }\end{array}$} & \multirow{7}{*}{$\begin{array}{l}\text { SIKA } \\
\text { FLOOR }\end{array}$} & \multirow{5}{*}{12} & 150 & 14 & 42.56 & Concrete cone failure \\
\hline & & & & 150 & 16 & 47.99 & Concrete cone failure \\
\hline & & & & 100 & 14 & 41.77 & Pull-out of the Anchor \\
\hline & & & & 100 & 16 & 42.50 & Pul3I-out of the Anchor \\
\hline & & & & 150 & 20 & 51.14 & $\begin{array}{l}\text { Concrete combined of splitting } \\
\text { and cone failure }\end{array}$ \\
\hline & & & \multirow{2}{*}{16} & 100 & 18 & 52.94 & $\begin{array}{l}\text { Concrete combined of splitting } \\
\text { and cone failure }\end{array}$ \\
\hline & & & & 100 & 20 & 56.28 & $\begin{array}{l}\text { Concrete combined of splitting } \\
\text { and cone failure }\end{array}$ \\
\hline
\end{tabular}




\subsection{Embedment length $\left(L_{D}\right)$ effect on pull-out capacity}

The second parameter studied was the effect of the embedment length $L_{D}$ on the bond strength via the pull- out test for the two types of epoxy adhesives KUT "NS", and SIKA FLOOR. In the present study two embedment lengths were investigated; 100 and $150 \mathrm{~mm}$ for two rebar diameters which of $12 \mathrm{~mm}$ and $16 \mathrm{~mm}$. Tables 9 and 10 showed that the values of the pull-out load directly increased as the embedment length increased for constant bar and hole diameters for both types of epoxy; KUT "NS", and SIKAFLOOR adhesives.

\subsubsection{Using KUT "NS"}

The effect of embedment length for KUT "NS" adhesive with fixed other parameters, i.e., diameter of bar $\left(d_{b}=12 \mathrm{~mm}\right)$ and hole diameter of $16 \mathrm{~mm}$, yielded that for $100 \mathrm{~mm}$ embedment length the pull out load was $44.08 \mathrm{kN}$ and $48.51 \mathrm{kN}$ for $150 \mathrm{~mm}$ embedment length as shown Table 10 and Fig. 10. Hence, as the embedded length increased from $100 \mathrm{~mm}$ to $150 \mathrm{~mm}$ the pull-out load increased by $10 \%$.

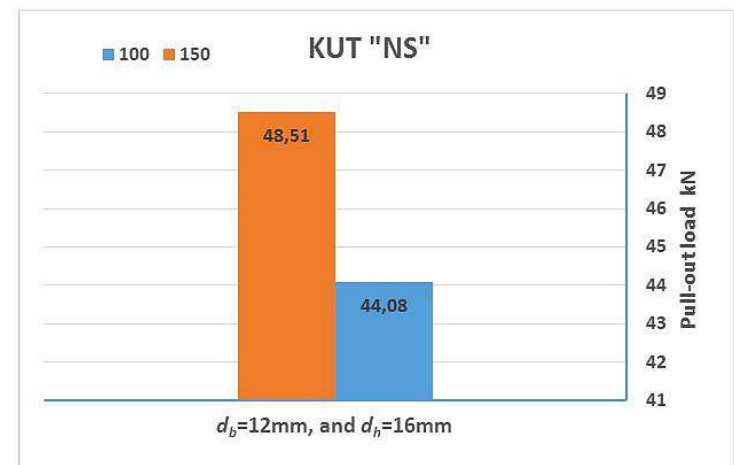

Fig. 10: The relation of the pull-out load with the embedment length for KUT "NS".

\subsubsection{Using SIKA FLOOR}

The results of the pull-out test recorded by using SIKA FLOOR adhesive, showed that the maximum pull out load increased directly with the increase of embedment length with a fixed diameter of bar $\left(d_{b}\right)$ parameter. The embedment length $100 \mathrm{~mm}$ with $\left(d_{b}=12 \mathrm{~mm}\right.$, and $\left.d_{h}=16 \mathrm{~mm}\right)$ gives 42.5 $\mathrm{kN}$ as the maximum value. While, for the embedment length, $150 \mathrm{~mm}$ the maximum value was 47.99 $\mathrm{kN}$, with increased percentage about $13 \%$ as shown in Table 10 and Fig. 11. It means that the pullout strength increases directly with the embedded length increase because of the higher bond stress distribution around the bar periphery and the pull-out load.

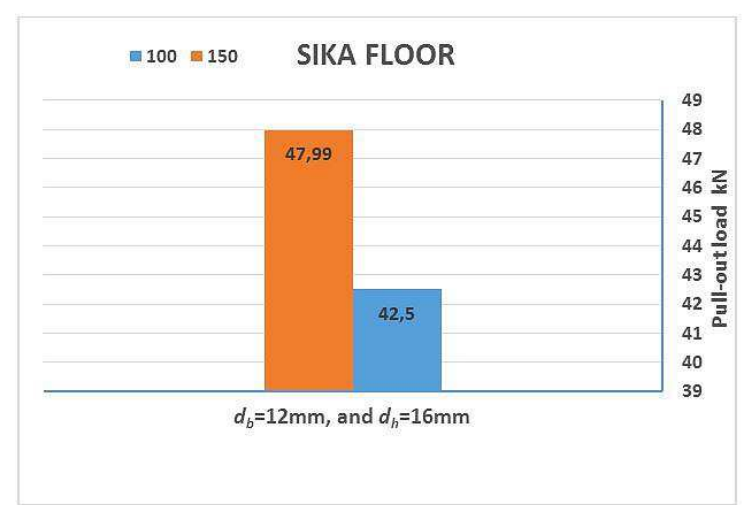

Fig. 11: The relation of the pull-out load with the embedment length for SIKAFLOOR.

\subsection{Diameter of hole ( $\mathrm{dh}$ ) effect on pull-out capacity}

The results of the effect of an increase in the diameter of the hole in concrete $\left(d_{h}\right)$ have positive influence on the pull-out load. 


\subsubsection{Using KUT "NS"}

The effect of an increase in the diameter of the hole in concrete $\left(d_{h}\right)$ has an appositive influence in pull-out load with using KUT "NS" epoxy as shown in Table 9 and Fig. 12. The maximum value recorded for $d_{h}$ with fixed all other parameters shows slightly increasing in pull out load with increasing diameter of the hole. For; $d_{b}=12 \mathrm{~mm}$, and $L_{D}=100 \mathrm{~mm}$ the pull out load value for $d_{h}=14 \mathrm{~mm}$ was $43.56 \mathrm{kN}$, while for $d_{h}=16 \mathrm{~mm}$ was $44.08 \mathrm{kN}$, with very small increases about $1 \%$. Also, for; $d_{b}=12$ $\mathrm{mm}$, and $L_{D}=150 \mathrm{~mm}$ the pull-out load value of $d_{h}=14 \mathrm{~mm}$ was $44.52 \mathrm{kN}$, while for $d_{h}=16 \mathrm{~mm}$ was $48.51 \mathrm{kN}$, with about $9 \%$ increases. Finally, when $d_{b}=16 \mathrm{~mm}$, and $L_{D}=150 \mathrm{~mm}$ the pull out load value of $d_{h}=18 \mathrm{~mm}$ was $58.38 \mathrm{kN}$, while for $d_{h}=20 \mathrm{~mm}$ was $61.14 \mathrm{kN}$, with a percentage of increased about $5 \%$.
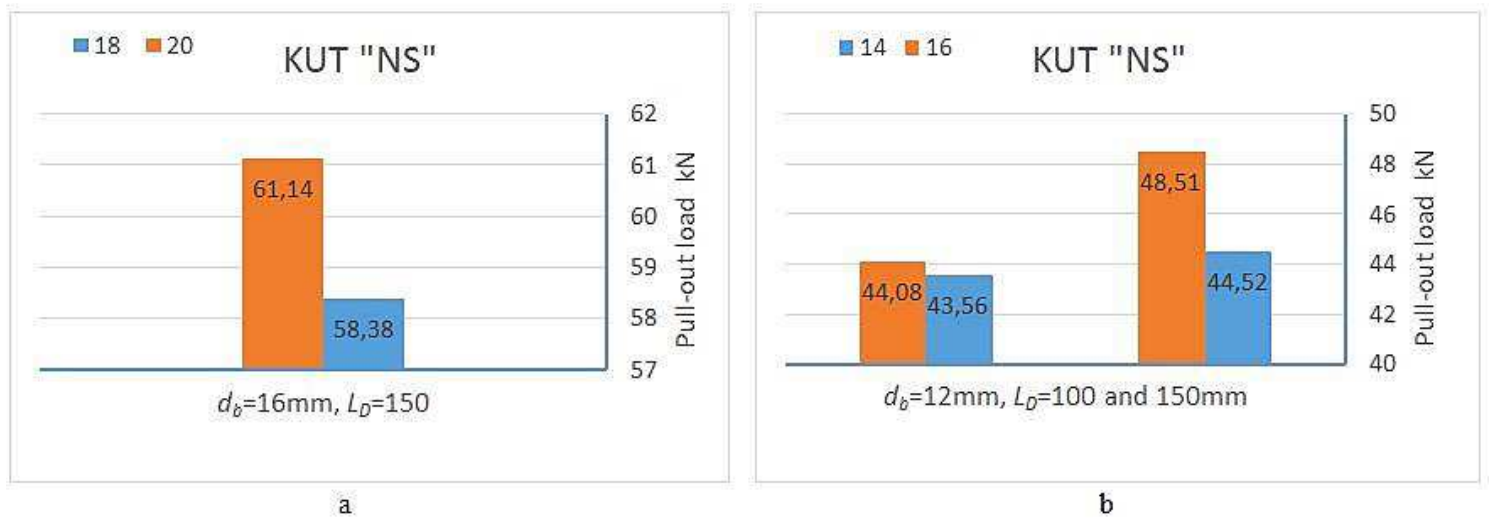

Fig. 12: The relation of the pull-out load with the diameter of the hole for KUT "NS".

\subsubsection{Using SIKAFLOOR}

From Table 10 for SIKAFLOOR epoxy, the values give direct behavior between the increased the diameter of the hole and increased the pull-out load. When $d_{b}=12 \mathrm{~mm}$, and $L_{D}=100 \mathrm{~mm}$ the pull out load value of $d_{h}=14 \mathrm{~mm}$ was $41.77 \mathrm{kN}$, while for $d_{h}=16 \mathrm{~mm}$ was $42.50 \mathrm{kN}$, with increasing percentage of $2 \%$. While, for; $d_{b}=12 \mathrm{~mm}$, and $L_{D}=150 \mathrm{~mm}$ the pull out load value of $d_{h}=14 \mathrm{~mm}$ was $42.65 \mathrm{kN}$ and for $d_{h}=16 \mathrm{~mm}$ was $47.99 \mathrm{kN}$ with increasing percentage of $13 \%$. Also for $d_{h}=20$ $\mathrm{mm}$ the pull out load was $51.14 \mathrm{kN}$, with increasing percentage of $27 \%$. On the other hand, when $d_{b}=$ $16 \mathrm{~mm}$, and $L_{D}=100 \mathrm{~mm}$ the maximum value of $d_{h}=18 \mathrm{~mm}$ was $52.94 \mathrm{kN}$, while for $d_{h}=20 \mathrm{~mm}$ was $56.28 \mathrm{kN}$, with increased percentage $6 \%$ as shown in Fig. 13.

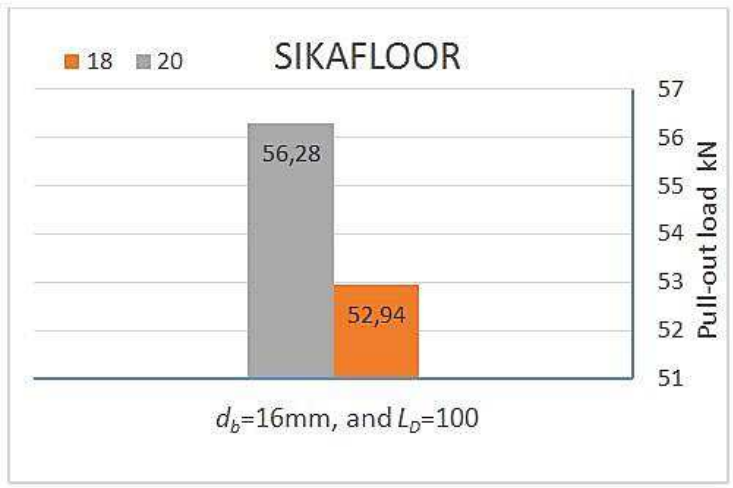

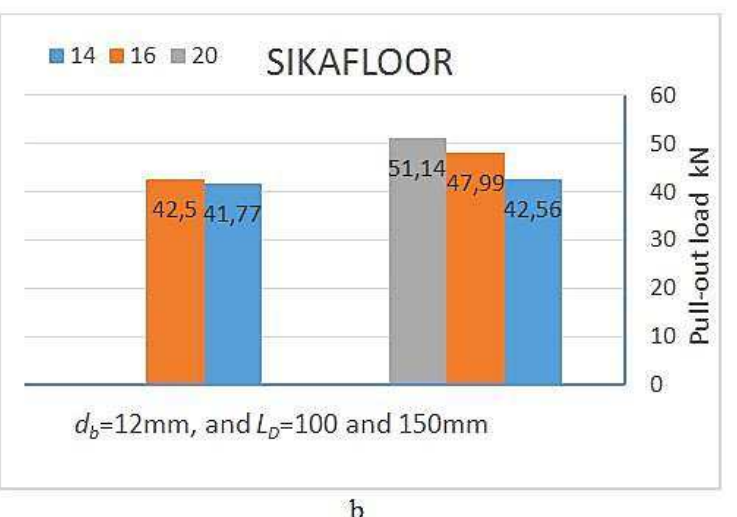

b

Fig. 13: The relation of the pull-out load with the diameter of the hole for SIKAFLOOR.

Generally, Tables 9 and 10, show that the hole diameter has slight effect on the pull out capacity compared to other parameters like embedment length and rebar diameter. From economical point of view, this conclusion is important in reduce the amount of adhesives required to install the anchors. 


\subsection{Effect of epoxy type on pull-out capacity}

The pull-out loads' results for the two types of epoxy were approximately closely as shown in Tables 9 and 10. However, with using KUT"NS", the results give a little better adhesive behavior in the tests compared with used the SIKAFLOOR epoxy. This is because the strength of KUT"NS" epoxy was higher than the SIKAFLOOR epoxy as mentioned previously in the 2.2.6 article. Where the maximum pull out load recorded was $61.14 \mathrm{kN}$ for KUT"NS" type of epoxy and $56.28 \mathrm{kN}$ was a record for SIKAFLOOR epoxy (the percentage difference was $8.5 \%$ ). While the minimum value of pull-out load was $43.66 \mathrm{kN}$ for KUT"NS" epoxy and $41.77 \mathrm{kN}$ for SIKAFLOOR for the same conditions (the percentage difference was $4.5 \%$ ).

\subsection{Rebar anchor systems effect on pull-out load}

In the present study two rebar-anchor systems investigated, namely cast in place system and post-installed system via adhesives. The results showed that for similar parameters (concrete characteristics, bar diameter and embedment length) the cast in place anchors showed higher pull out capacity in all cases compared to post installed anchors as shown in Tables 9 and 10. For embedment length of $100 \mathrm{~mm}$ the cast in place system, yielded pull out capacity of $79.83 \mathrm{kN}$ and $68.74 \mathrm{kN}$ for bar diameter of $16 \mathrm{~mm}$ and $12 \mathrm{~mm}$ compared to post installed system, which yielded $56.28 \mathrm{kN}$ and 44.08 $\mathrm{kN}$, respectively. Thus the cast in place anchor showed pull out load greater than post installed anchors by $41.8 \%$ and $55.9 \%$ for bar diameters of $16 \mathrm{~mm}$ and $12 \mathrm{~mm}$ respectively.

For embedment length of $150 \mathrm{~mm}$ the cast in place system, yielded pull out capacity of 87.86 $\mathrm{kN}$ and $76.59 \mathrm{kN}$ for bar diameter of $16 \mathrm{~mm}$ and $12 \mathrm{~mm}$ compared to post installed system, which yielded $61.14 \mathrm{kN}$ and $51.14 \mathrm{kN}$, respectively. Thus, the cast in place anchor showed pull out load greater than post installed anchors by $43.7 \%$ and $49.76 \%$ for bar diameters of $16 \mathrm{~mm}$ and $12 \mathrm{~mm}$ respectively.

When summarized the results it can be observed that the pull-out capacity for cast in place anchor is about $50 \%$ greater than that of post installed anchors for embedment length ranged from 100-150 mm.

\section{Failure modes}

The mode of failure of tested specimens under axial loading for the two types of epoxy is shown in Tables 9 and 10. Where the concrete splitting failure had occurred in more the tested specimens because of the high bond between concrete, adhesive, and anchor bar. The other failure occurred is cutting apart from concrete like a cone. Concrete cone failure also occurs with pull-out failure in some of the tested specimens because of the high bond just between adhesive, and anchor bar. There was no sign of steel failure (shear) in the anchor bar. This implies that the bond strength between the rebar-concrete interfaces is weaker than the yield strength of the rebar, which emphasis to use embedment lengths practice greater $150 \mathrm{~mm}$ in order that the rebar get its full capacity as tension bar before bonding failure. Figs. 14 to 17 show all patterns of failures mentioned previously.

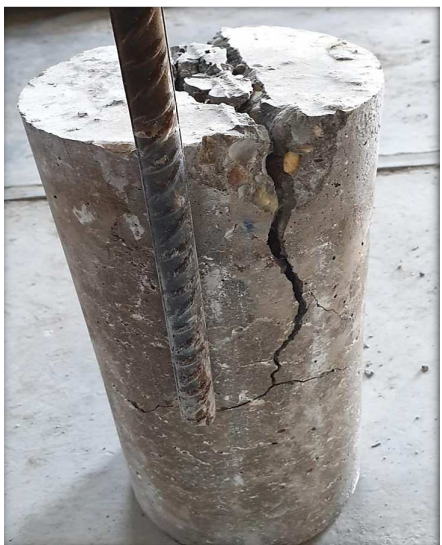

Fig. 14: Concrete splitting failure.

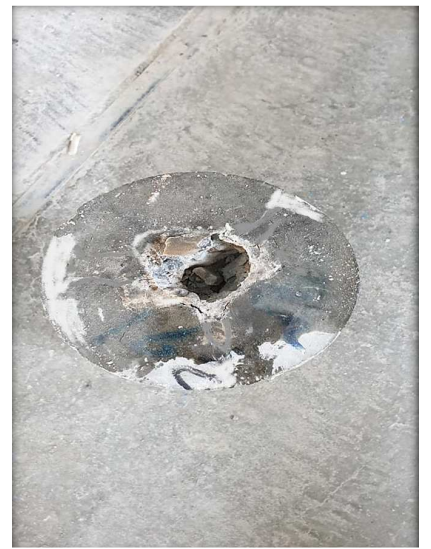

Fig. 15: Concrete cone failure.

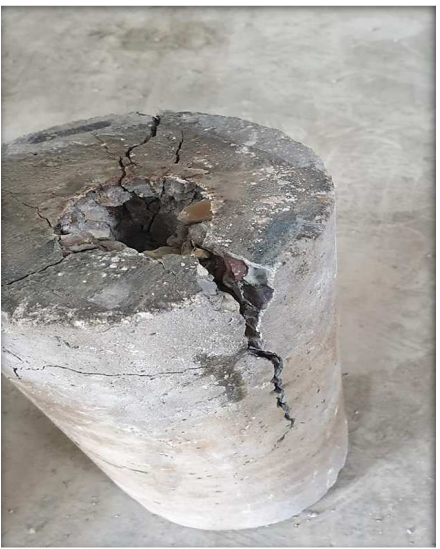

Fig. 16: Concrete combined of splitting and cone failure. 

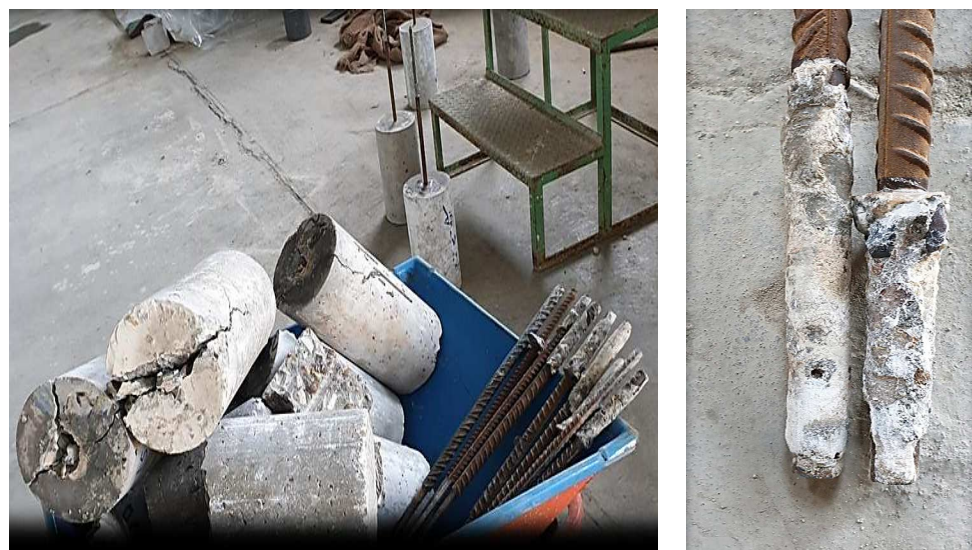

Fig. 17: No steel failure (shear) in the anchor bar.

\section{Conclusion}

From the experimental results, the following conclusions can be summarized:

1. The pull-out load increases with increases in the rebar diameter, where the pull-out capacity is increased by $26 \%$, and $32 \%$ as the bar diameter increased from $12 \mathrm{~mm}$ to $16 \mathrm{~mm}$ for KUT "NS" and SIKAFLOOR epoxy adhesives, respectively. This implies that the increase in the contact surface of the rebar with the binder or adhesive, lead to an increase in the bond strength or the recordable pull-out load.

2. The pull-out strengths of control samples - cast in place - recorded higher values from postinstalled samples by about $50 \%$. Although the results of KUT"NS" and Sikafloor adhesives gave an accepted average pull-out load value. So post-installed rebar anchor is reliable.

3. The parameters which have a slight effect on the pull-out capacity was hole diameter, where the average increased recorded for the two types of epoxy was $6 \%$.

3. The pull-out strengths of the two chemical adhesives - KUT"NS" and Sikafloor - were very close where the average difference was $6.5 \%$. Although, the results of KUT"NS" adhesive gave relatively a little better pull-out strength in several samples, so it can use Sikafloor with filler in rebar anchor system, It is also low cost compare with KUT"NS".

4. The failure mode of post-installed rebar concrete governed by the rebar area of contact with the adhesives or binder and embedded lengths. The larger diameter of rebar favors splitting or failure of concrete due to higher strength in binder-rebar interface compare to the binder-concrete interface. The $16 \mathrm{~mm}$ diameter rebar was found to be dominated by splitting, while $12 \mathrm{~mm}$ rebar specimens were characterized by the combination of splitting and pull-out of rebar. While the concrete conical shape failure depending on the type of binding agents and the embedded length.

\section{References}

[1] DROESCH, D. D.: Bonded Anchors in Concrete under Sustained Loading. M.Sc. Thesis, University of Massachusetts Amherst, USA, July 2015.

[2] TAYEH, B. A. - EL DADA, Z. M. - SHIHADA, S. -YUSUF, M. O.: Pull-Out Behavior of Post Installed Rebar Connections Using Chemical Adhesives and Cement Based Binders. Journal of King Saud University, Engineering Sciences, 2017.

[3] GONZÁLEZ, F. - FERNÁNDEZ, J. - AGRANATI, G. - VILLANUEVA, P.: Influence of Construction Conditions on Strength of Post Installed Bonded Anchors. Constr. Build. Mater, Vol. 165, 2018, pp. 272-283.

[4] EPACKACHI, S. - ESMAILI, O. - MIRGHADERI, S. R. - BEHBAHANI, A. A. T.: Behavior of Adhesive Bonded Anchors under Tension and Shear Loads. Journal of Constructional Steel Research, Vol. 114, 2015, pp. 269-280.

[5] ÇALISKAN, Ö. - ARAS, M.: Experimental Investigation of Behavior and Failure Modes of Chemical Anchorages Bonded to Concrete. Constr. Build. Mater, Vol. 156, 2017, pp. 362-375.

[6] ASSAAD, J. J. - ISSA, C. A.: Bond Strength of Epoxy-Coated Bars in Underwater Concrete. Constr. Build. Mater, Vol. 30, 2012, pp. 667-674.

[7] BRENCICH, A.: A Post-Installed Insert for Pull-Out Tests on Concrete up to $70 \mathrm{MPa}$. Constr. Build. Mater, Vol. 95, 2015, pp. 788-801. 
[8] CALIS KAN, Ö. - YILMAZ, S. - KAPLAN, H. - KIRAÇ, N.: Shear Strength of Epoxy Anchors Embedded into Low Strength Concrete. Constr. Build. Mater, Vol. 38, 2013, pp. 723-730.

[9] COOK, R.: Behavior of Chemically Bonded Anchors. J. Struct. Eng., Vol. 119, Iss. 9, 1993, pp. 2744-2762.

[10] COOK, R. - KONZ, R.: Factors Influencing Bond Strength of Adhesive Anchors. Struct. J., Vol. 98, Iss. 1, 2001, pp. 76-86.

[11] ELIGEHAUSEN, R. - COOK, R. - APPL, J.: Behavior and Design of Adhesive Bonded Anchors. ACI Struct. J., Vol. 103, Iss. 6, p. 822.

[12] FUJIKAKE, K. - NAKAYAMA, J. - SATO, H. - MINDESS, S. - ISHIBASHI, T.: Chemically Bonded Anchors Subjected to Rapid Pullout Loading. ACI Mater. J., Vol. 100, Iss. 3, 2003, pp. 246-252.

[13] GESOGLU, M. - ÖZTURAN, T. - ÖZEL, M. - GÜNEYISI, E.: Tensile Behavior of Post installed Anchors in Plain and Steel Fiber-Reinforced Normal-and High-Strength Concretes. ACI Struct. J., Vol. 102, Iss. 2, 2005, p. 224.

[14] KIM, J. - JUNG, W. - KWON, M. - JU, B.: Performance Evaluation of the Post-Installed anchor for Sign Structure in South Korea. Constr. Build. Mater, Vol. 44, 2013, pp. 496-506.

[15] MAZILIGÜNEY, L.: Tensile Behavior of Chemically Bonded Post-Installed Anchors in Low Strength Reinforced Concretes. (MSc. Thesis). Middle East Technical University, pp. 28-33.

[16] SHAH, A. - ALI, Q. - ALAM, B. - SHAHZADA, K. - KHAN, R. - AHMAD, N.: Study on Performance Evaluation of Adhesive Anchors in Concrete. Int. J. Adv. Struct. Geotech. Eng., Vol. 1, Iss. 2, 2012, pp. 74-78.

[17] YILMAZ, S. - ÖZEN, M. - YARDIM, Y.: Tensile Behavior of Post-Installed Chemical Anchors Embedded to Low Strength Concrete. Constr. Build. Mater, Vol. 47, 2013, pp. 861-866.

[18] KUT Epoxy Anchor. Product Data sheet: Epoxy Resin Based Anchoring Grouts. GAP-04-1110, Specialties Construction Chemicals Factory (ASPEC).

[19] SIKAFLOOR-169, Product Data sheet: Part Epoxy Binder for Mortars, Screeds and Seal Coats, 2017. 